and "alarum venis fere obsoletis" would certainly apply to the venation. Another feature common to both specimens is the entirely light yellow tarsi, only the claws being black. All of the other species have the terminal joint blackish.

Acrocera fumipennis Westwood.

This may prove to be only a dark form of the preceding species. The entire absence of yellow markings in the description and the statement that the base of the wings is smoky brown, cannot however apply to those I have seen with obsolete venation.

\title{
A NEW BOG-INHABITING VARIETY OF FORMICA FUSCA L.
}

\section{By William Morton Wheeler.}

Several entomologists have recently called attention to the ants inhabiting peat-bogs in Northern Europe. Nylander, as long ago as 1846, described a peculiar, shining black Formica as $F$. picea from Sphagnum bogs in Finland ${ }^{1}$ and this species has since been collected in Germany, Denmark, England, Russia and Siberia but has been usually referred to $F$. gagates Latreille, a form described from France. Emery ${ }^{2}$ first definitely recognized the two forms as distinct, though he regarded both as subspecies of fusca. He gave the distribution of gagates as Southern Europe and Asia Minor and that of picea as Northern Europe and Asia as far as China, whence it had been recorded by Forel under the name of filchneri. Forel has since described a var. formose of picea from the Island of Formosa. ${ }^{3}$

In 1913 Donisthorpe found picea in England nesting in Sphagnum, ${ }^{4}$ in 1914 Adlerz found it in the same situations in Sweden, ${ }^{5}$ and during the same year and 1915 Bönner published two inter-

\footnotetext{
1 Adnotationes in Monographiam Formicarum Borealium Europae, Act. Soc. Sc. Fenincæ, 2, 1846, pp. 875-994 and Additamentum Adnotationum in Monogr. Form. Bor. Eur. Ibid., pp, 1048-1062.

2 Beiträgə zur Monographie der Formiciden des paläarktischen Faunengebietes, VII, Deutsch Ent. Zeitschr. 1909, pp. 179-204, 16 fgs.

${ }^{3}$ H. Sauter's Formosa-Ausbeute: Formicidæ II. Arcb. f. Naturg. 79, 1913, pp. 183-202.

4 Myrmecophilous Notes for 1912. Ent. Record 25, 1913, pp. 61-68, 89-97.

${ }^{5}$ Formica fusca picea Nyl. en Torfmossarnas Myra. Ark. f. Zool. 8, 1914 p. 1.
} 
esting papers on the habits of picea as observed in the Sphagnum bogs near Copenhagen. ${ }^{1}$ He describes in detail its small mound nests in the clumps of wet Sphagnum and shows how it hibernates in these nests, which are frozen solid during the winter months. Bönner's observations induced Forel to search for $F$. picea in some peat-bogs near Yvorne, Switzerland, a country from which the ant had not been recorded. He succeeded in finding it, and from a study of his specimens concluded that it is to be regarded as a distinct species. ${ }^{2}$

The wide distribution of picea in boreal Eurasia led me to hope that I might find it or a closely related form in the peat-bogs of New England. I therefore gladly accepted the invitation of Prof. R. T. Fisher, director of the Harvard Forest, to explore with him a large peat-bog at Petersham, Mass. This bog is at an altitude of over 700 feet. . Its flora has a pronounced boreal facies as shown by the following lists of plants which were abundant in such portions of it as we could conveniently enter: Picea mariana and canadensis, Larix laricina, Chamceodaphne calyculata, Kalmia angustifolia and polifolia, Ledum grœnlandicum, Rhododendron canadense and Oxycoccos oxycoccos. I did not find picea in this bog but instead a variety of fusca L., evidently distinct, of which I had received specimens from Sphagnum bogs in other localities. I had erroneously included this form in $F$. fusca var. gelida Wheeler in my recent "Revision of the Genus Formica (Linné) Mayr."3 Only one small colony of the ant was found and this was nesting under a $\log$ in damp, peaty soil. On again examining my series of gelida, I find that all the specimens cited from Eastern North America, i. e., from Labrador, Quebec, Newfoundland, Ontario and Nova Scotia, and a few specimens mostly taken in Sphagnum bogs in New Hampshire, Maine, Michigan and New York and partly referred to $\boldsymbol{F}$. fusca var subcenescens Emery, belong to this distinct unpublished variety which differs from the true var. gelida in the pubescence and sculpture of the gaster and the color and sculpture of the thorax. I have seen only worker and female specimens answering to the following description:

\footnotetext{
${ }_{3}$ Formica fusca picea eine Moorameise. Biol. Centralbl. 34, 1915, pp. 59-76, 6 tggs. and Die Ueberwinterung von Formica picea und andere biologische Beobachtungen. Ibid. 35, 1915, pp. $65-77,1 \mathrm{pl}$.

2 Deux Nouveautés Myrmécologiques, September 1, 1914, 1 p. (author's publication).

3 Bull. Mus. Comp. Zool. 53, 1913, pp. 379-565, 10 maps.
} 
Formica fusca L. var. algida var. nov.

Worker. Length 3.5-5.5 mm.

Head not longer than broad, except in the smallest individuals, slightly narrowed in front, with rather convex sides. Epinotum distinctly and often sharply angulate in profile. Petiole convex in front, flattened behind with transverse. feebly rounded, entire border, precisely as in the vars. neorufibarbis and gelida. Upper surface of head and thorax much more opaque and more coarsely shagreened than in these varieties. Frontal area shining. Gaster much more shining than in the varieties mentioned, though sharply shagreened, its hairs short, blunt and sparse, its pubescence much sparser and distinctly longer and coarser, except on the anterior portion of the first gastric segment, where it is very fine and dense as in gelida and neorufibarbis. Pubescence on head, especially on its sides, long and dilute. Color variable; dark reddish brown; cheeks, mandibles and clypeus paler; gaster and posterodorsal portions of head and in many specimens also the thorax and petiole, black. Thorax, however, usually paler than the head and in many Newfoundland specimens pale brownish red, as in neorufibarbis, but with a dark cloud on the pro- and mesonotum as in gelida. In these specimens the pale color extends also to the petiole and base of the first gastric segment. Other specimens have the thorax dark brown, with paler and more reddish sutures. Legs reddish brown, usually with the coxæ, femora and tibiæ dark brown or blackish, except at the articulations. Antennæ reddish brown, funiculi infuscated, except at the base.

Female. Length 6.5-6.8 mm.

Resembling the worker in pilosity and pubescence, except that the latter on the gaster is even more dilute and longer and the surface of this region is more delicately shagreened and more shining. The petiole is broader and more compressed anteroposteriorly, with more acute border, which is entire and often slightly produced upward in the middle. The color is similar to that of the lightest workers, the thorax, petiole, legs and anterior and ventral portions of the first gastric segment being clear brownish red. Pronotum with brownish anterior and posterior borders, pleuræ more or less clouded with brown; mesonotum with three more or less sharply defined, longitudinal dark brown or blackish blotches; metanotum and posterior border of scutellum more or less infuscated. Wings colorless, with brown veins and apterostigma.

Maine: Kittery Point, in Sphagnum bog (R. Thaxter), type locality.

New Hampshire: Lafayette, 4,000 feet in Sphagnum bog (J. H. Emerton); Mt. Washington, 3,840 feet (W. Reiff).

Massachusetts: Petersham, in Sphagnum bog (Wheeler).

New York: Bedford, nesting in dead leaf of Sarracenia, in Sphagnum bog (Wheeler).

Michigan: Porcupine Mountains and Isle Royale (O. McCreary).

Ontario: Kenora (J. C. Bradley).

Quebec: Saguenay R. (Geo. Engelhardt); Anticosti I., Mingan 
I. and Neapisca I. (Saml. Henshaw); East Maine R. (A. Skinner). Nova Scotia: Digby (J. Russell).

Newfoundland: Bay of Islands (L. P. Gratacop.), Spruce Brook, Port Saunders, Port au Croix (Amer. Mus. Nat. Hist.); Seldome Come Bay, Fogo I. (O. Bryant).

Labrador: Square I. (A. S. Packard); St. Lewis Inlet.

The varieties neorufibarbis, gelida and algida are all very closely related boreal fusca forms, the first, as I have noticed during the past summer, common in the Sierra Nevada Mountains, Selkirks and the Canadian Rockies at elevations between 4,000 and 5,000 feet, the second ranging from Alaska to higher elevations in the Sierra Nevada and Rocky Mountains of Colorado and New Mexico, and the last peculiar to boreal eastern North America, where it occurs at low elevations from Labrador to New York and as far west as Western Ontario, but, so far as known, only in peat bogs within the United States.

Besides $\boldsymbol{F}$. fusca var. algida there are several species of ants that nest frequently or by preference in the cold bogs of the Northern States and British America. The most frequently met with in such situations are, according to my observations, the following: Myrmica brevinodis Emery vars. canadensis Wheeler, and sulcinodoides Emery, Myrmica scabrinodis Nyl. var. detritinodis Emery and subsp. schencki Emery var. emeryi Forel, Leptothorax (Mychothorax) emersoni Wheeler and its subsp. glacialis Wheeler, Crematogaster lineolata Say and its subsp. pilosa Pergande, Dolichoderus (Hypoclinea) taschenbergi Mayr var. aterrimus Wheeler, Lasius niger L. vars. sitkaënsis Pergande and neoniger Emery, Lasius (Chthonolasius) umbratus Nyl. subsp. minutus Emery, Formica fusca L. (typical), Formica cinerea Mayr vars. neocinerea Wheeler and altipetens Wheeler, Camponotus herculeanus L. var. whymperi Forel and subsp. ligniperda Latr. var. noveboracensis Fitch. In the bog at Petersham, Mass., a worker major of Camponotus whymperi was found in the liquid contents of a pitcher plant leaf (Sarracenia purpurea). It is probable that this list will be considerably increased by further attention to the ants inhabiting our northern peat-bogs. 

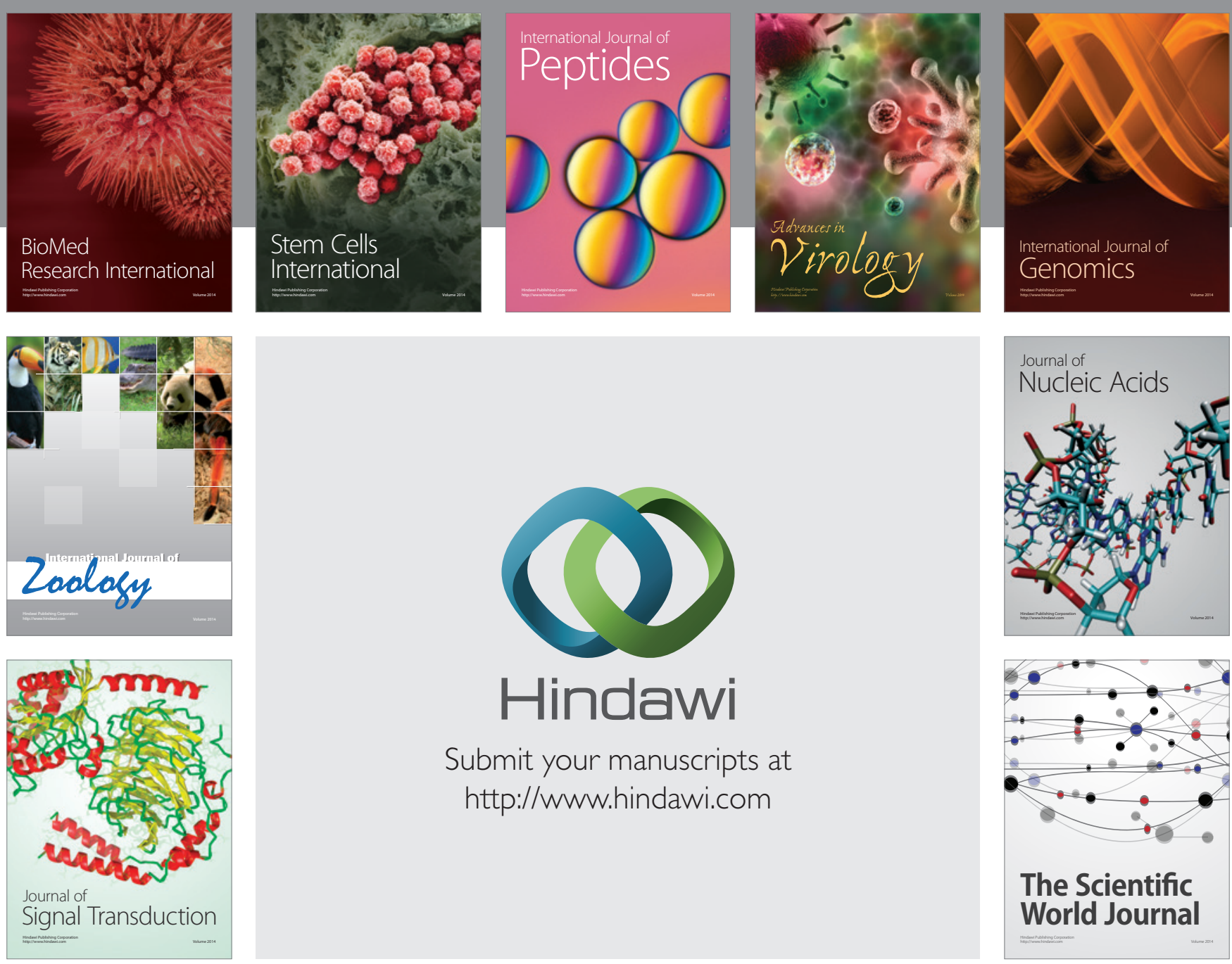

Submit your manuscripts at

http://www.hindawi.com
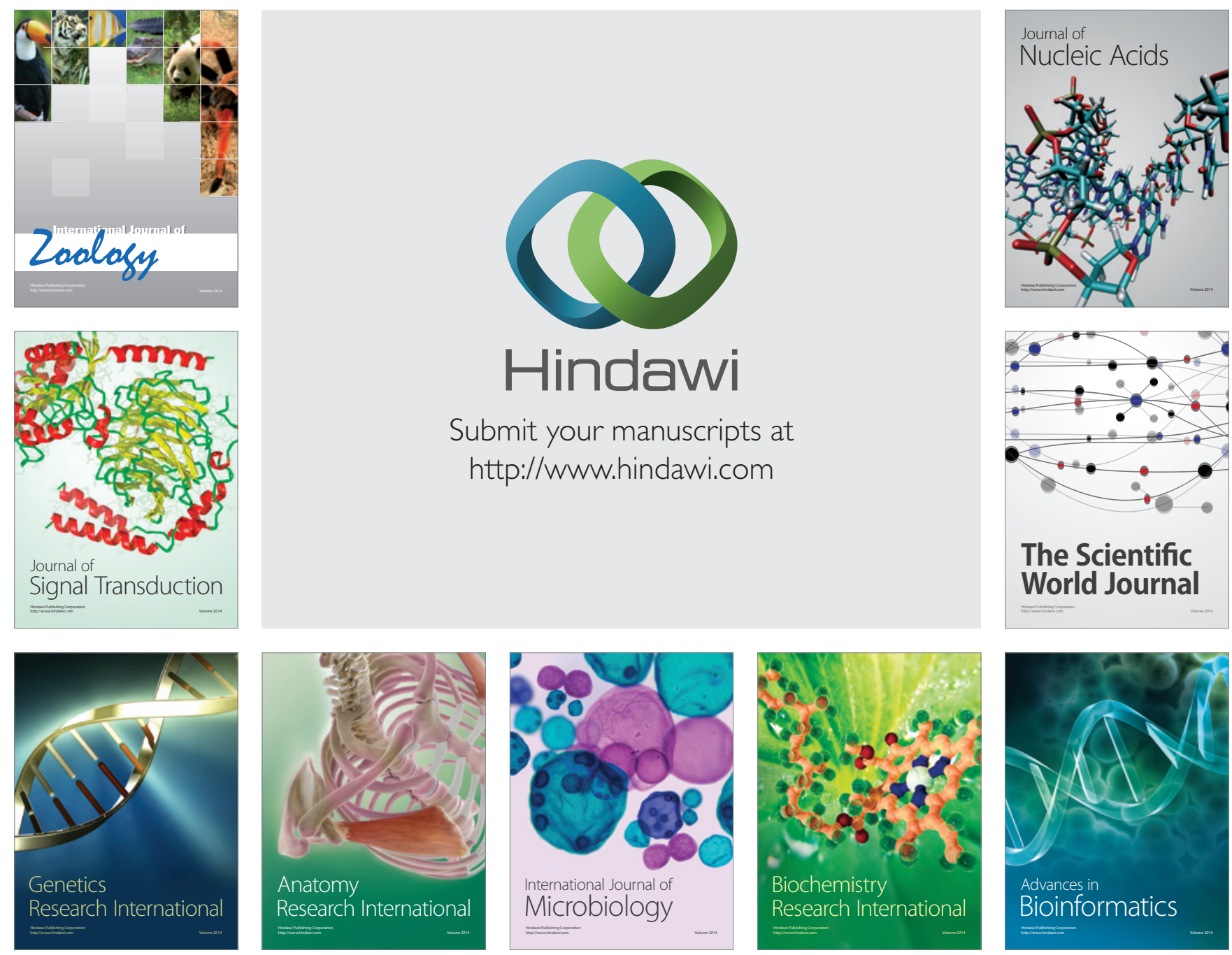

The Scientific World Journal
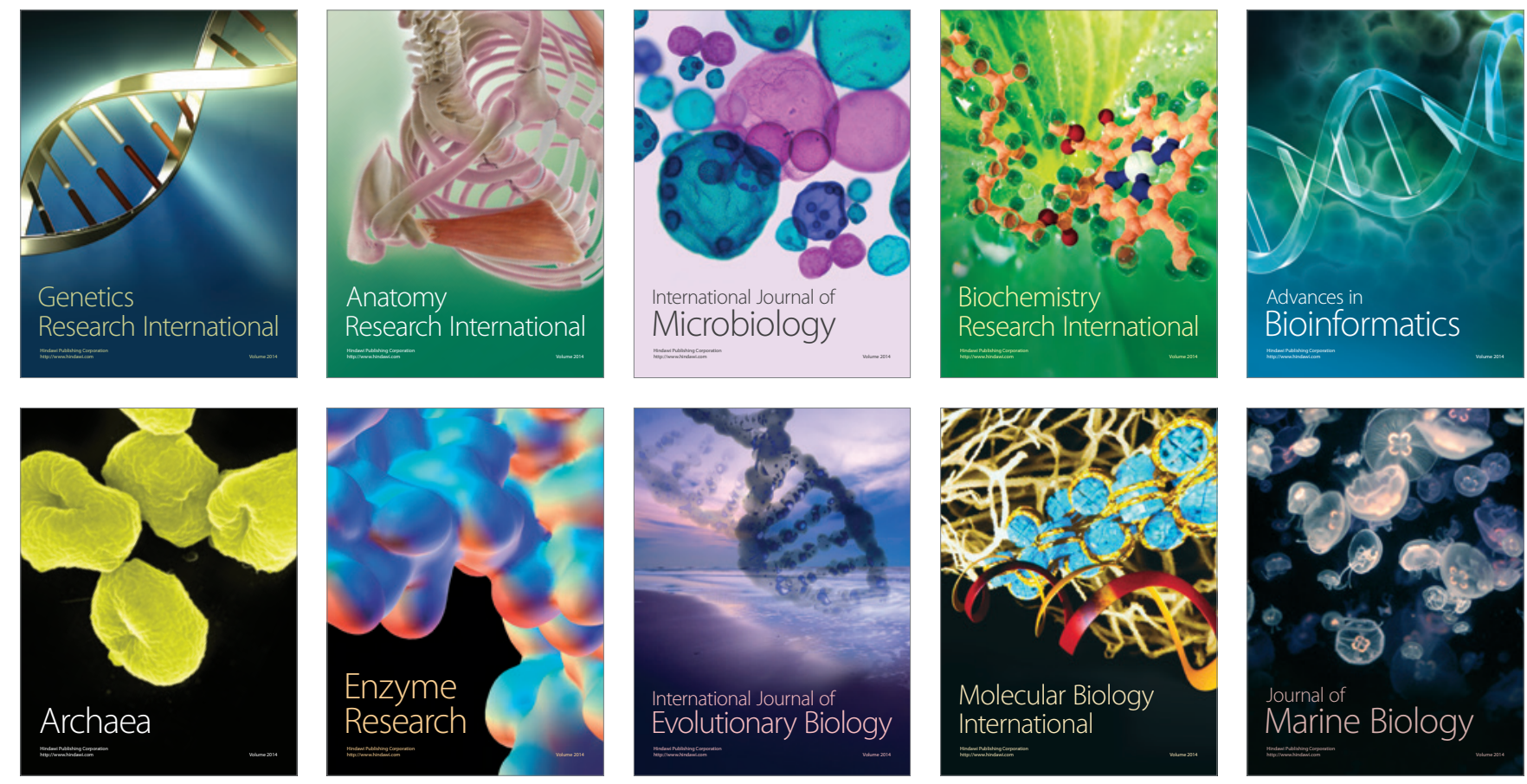